\title{
The Impact of Declining Fertility on Children, Parents and Policy
}

\author{
Ann Buchanan \\ Department of Social Policy and Intervention, University of Oxford, Oxford, UK \\ Email: ann.buchanan@spi.ox.ac.uk \\ Received 20 July 2014; revised 5 September 2014; accepted 23 September 2014 \\ Copyright (C) 2014 by author and Scientific Research Publishing Inc. \\ This work is licensed under the Creative Commons Attribution International License (CC BY). \\ http://creativecommons.org/licenses/by/4.0/

(c) (i) Open Access

\begin{abstract}
This paper, based on an international study of declining fertility, highlights the impact on children, parents and policy. Though in general, fewer children per family, are associated with young people's increased health, well-being and education, the increase in the numbers of elderly will put pressure on women to carry the burden of, not only caring for their young, but also large numbers of elderly relatives, while at the same time contributing to a declining work force. Although there is little evidence that lone children do worse than children from a two-child family, the pressure on young people is great as they bear the hopes and aspirations of their family members and their societies to fill the gap in a world with fewer children. The paper concludes that social policy the world over will need to be alert to the impact of changing demography and the importance of investing in children so that they can contribute in a future world where they will be at a premium.
\end{abstract}

\section{Keywords}

Fertility, Children's Well-Being, Families Well-Being, Family Policy

\section{Introduction}

"The last decades of the twentieth century witnessed a major transformation in world fertility: the total fertility - the average number of children a woman would bear if fertility rates remained unchanged during her lifetime-fell from 4.4 children per woman in 1970-1975 to 2.5 children per woman in 2005-2010" [1].

Although declining fertility is a global issue, the phenomenon is particularly pronounced in the Developed World and East Asia. The one-child family is not just a feature of China but is also common in Japan, Korea and other "tiger" countries [2]. In any society, women need to average out at 2.1 children over their life course in order to replace the population. Across Europe, North American, Australia and East Asian, fertility rates in most countries remain below 2. Among the 201 countries with at least 90,000 inhabitants, 71 countries recorded by 
sthe United Nations in 2013, had below-replacement fertility and all these countries were in Eastern Asia or Europe. Thirty two countries had fertility above 5 children per woman and all but two of these countries were in sub-Saharan Africa [1]. Falling fertility however is not the same as population decline. Increasing numbers of the elderly will, with better health care, survive into very old age. However demographers estimate that by 2050 as the older members of society pass away and fewer children are born, the global population will start to go down.

The aim of the study of which this paper is apart [3] was to explore this phenomenon by bringing together the world's leading scholars from a range of disciplines, to assess the facts, postulate the possible reasons and finally consider the possible implications. The remit of this paper, is to consider what might be the impact on children and parents.

\section{The Reasons for Falling Fertility}

Scholars from different areas of the world examined the situation in their country and the possible reasons for falling fertility. In general, the availability of contraception giving women choice in how many children they would have; the increased in educational opportunities for women and a subsequent work opportunities; plus the difficulties of arranging care for children and the cost of this, were cited as the main reasons [4]. But there were other additional causes operating in various parts of the world. The idea was to look not only at the statistical trends in each country but to explore studies using qualitative material to assess the mindsets behind falling fertility.

In China and East Asia, the one child family has almost become a social norm [2] Professor Zheng of the Chinese Academy of Social Science [5] found that following the one-child policy, young parents who had been lone children and who were now permitted to have two children, did not want this. The one child family had become accepted as the "proper size for a family". Although there was no such policy in Taiwan, Hong Kong or Singapore a similar situation existed. In the Russia, however, there were different pressures operating. Following the fall of Communism, the dire economic situation persuaded families to limit their families while they waited until the economy improved [6]. For some, the wait proved too long and they missed the fertility window. In South Africa, it was difficult to tell exactly what was happening, but HIV/AIDS had impacted on fertility because children were not born to parents who had died or were sickly [7]. In the developed world and also in East Asia, a growing number of woman remained childless, either by choice or they found themselves unable to conceive [8] [9]. In South America families were persuaded to limit their families by watching docu-soaps [10]. Basten, who investigated this phenomen demonstrated how women were strongly influenced to limit or increase their families by watching the celebrity culture. In the UK after many years of falling fertility, fertility rates actually rose from 1.7 to 1.9 . This is felt to be largely due to the increasing number of immigrants coming to Britain to work at the same time they are forming their families [11].

\section{Impact on Families of Caring for Increasing Number of Elderly}

Globally it is estimated the number of people aged over 60 will reach 1 billion by 2020 doubling to 2 billion by 2050 representing over one fifth of the world's population. Correspondingly the proportion of young will fall to less than one fifth globally by the middle of the century [11]. If we take an age structural change perspective we can view population change in terms of a shift between providers and dependents—-the dependency ratio—and how this will typically move from a large percentage of young to large percentage of old dependents.

Elderly Dependency Ratios (EDR) measure the number of persons of working age (aged 15 to 64) per person aged 65 or over. For many countries the rise in the EDRs will be significant. It is forecast to almost double in Africa, Europe, Northern America and Oceania; almost triple in Asia and will more than triple in Latin America and the Caribbean. By 2050, the ratio of persons aged 65 or over to those of working age is projected to grow from currently 6:100 to 11:100 in Africa, from 10:100 to 27:100 in Asia, from 10:100 to 31:100 in Latin America and the Caribbean, from 16:100 to 30:100 in Oceania, from 19:100 to 36:100 in Northern America and from 24:100 to 47:100 in Europe [12]. The next decade will thus see a rapid shift towards increased EDRs in most industrialised countries. Practically what this means is that fewer young people will be available to support an increasing number of the elderly. As the population ages, there will also be an increasing number of the very old, who will live longer because of better health care. It is this group who will place particularly demands for resources and support on the parents of the next generation, who in addition to rearing their own children, will be 
likely to be also working outside the home.

As the number of available working age young people decrease, an increasing number of the elderly will be needed to, and may want to, continue to work past age 65. This poses another dilemma. Across the world, while parents work, grandparents have been an important source of child care. In the UK, the childcare grandparents provide has been valued at $£ 7.3$ billion [13]. If grandparents are working, this resource will not be available. In many parts of the world, grandparent care may be the only child care available.

\section{Impact on Children Globally}

In the main declining fertility is a good news story for children. As the United Nations report "Declining fertility has ... contributed to poverty reduction. Between 1960 and 2000, demographic change alone accounted for a 14 per cent drop in poverty levels in developing countries and could produce an additional 14 per cent reduction during 2000 to 2015” [14]. The UN 2010 Development Report [15] notes rapid progress around the world as measured by the Human Development Index (HDI). This index measures development by combining life expectancy, educational attainment and income into a composite indicator. Are children living longer? Are they better educated? Are they less poor? The world's average HDI has increased by 18 per cent since 1990 and 41 per cent since 1970 [16]. Overall mortality rates have fallen faster in infants and children than in adults. If mortality rates of the 1970s were applied today, nearly 7 million more children would have died. The decline in infant mortality is faster in developed countries. So the good news is that children globally are generally healthier, better educated and less poor.

The darker side of the story is that the HDI does not measure the gross inequalities within countries. The overall level of inequality in a country, region or population group-and more generally the distribution of consumption, income or other attributes which is an important dimension of welfare — can be indicated by the Gini Index. The index used by the United Nations Development Report [17], broadly speaking, measures difference in consumption between the richest 10 per cent in a country and the poorest 10 per cent. The lower the score, the smaller the difference between the richest and the poorest. While Norway topped the list under the HDI, their Gini index at 25.8 (UNDP 2009), assessed during 1992-2007, shows that there was a level of inequality which was marginally higher than Sweden at 25. Levels of inequality are considerably higher in the USA at 40.8, which is very similar to China at 41.5 .

Another dark fact of fertility decline is the impact of gender preference. In strongly patriarchal societies, where the cultural and economic value of sons is at a premium, the preference for a son manifests itself in many ways, ranging from differential allocation of household resources, medical care and neglect of girl children to female infanticide. In addition, with the increasing availability of ultrasound in the mid-1980s, sex determination followed by sex-selective abortion began to become widespread [18]. "Normal" sex ratio at birth is in general between 103 and 107 male live births per 100 female live births. Since the early 1980s, the use of sex-selective abortion has increased in many Asian contexts. Estimates indicate that several million female foetuses were aborted in the last two decades of the twentieth century.

\section{Impact on Children of Being Part of a Smaller Family}

Moving from the macro-picture of the impact of low fertility, we may wonder how individual children fare particularly those brought up as an only child. What impact does having no brothers or sisters have on the modern child? History is replete with harsh stereotypes of the self-centred, selfish only child. Stanley Hall, one of the early developmental psychologists in the USA, reportedly said that to be an only child "was a disease in itself" [19].

Despite historical views, psychological research demonstrates that the earlier negative opinion of the lone child is not supported. Toni Falbo from the USA, in a series of high quality studies, has spent much of her academic career disproving the stereotype of the self-centred, selfish only child. In a meta-analysis [20] of 115 studies measuring achievement, adjustment, character, intelligence, parent-child relationships and sociability, only children surpassed all others except first-borns on achievement and intelligence, and across all developmental outcomes only children were found to be indistinguishable from first-borns and those from small families. However, she found, as with all families, that parent-child relationships were critical.

We may wonder what difference the lack of brother and sisters have over the life course. In a study using the Netherlands Kinship Panel Study [21], the authors note that "the sibling tie is the family relationship with the 
longest duration". Although parental relationships are essentially dyadically based, they are subject to the influence of the network in which they are embedded. Siblings may be an important part of that network. In another study of Toronto social networks [22] it was found that kin were providing five types of sibling support: emotional aid; services; financial aid; companionship, housing, or job information; and complementary parenting to children. Nearly a quarter of emotionally supportive relations were provided by siblings. Children with no brothers or sisters may miss out not only in the companionship of childhood but also the support in old age.

For only children, in the highly competitive environment of Beijing and other East Asian countries, their "loneness" will bring other pressures. The Confucian tradition, so central in many Asian societies, emphasizes education and study [23]. Confucius disparaged those who had faith in intuition and argued that the only real understanding of a subject comes from long and careful study. It is one of the enduring global dilemmas that as standards of health, education and wealth rise [24], levels of happiness fall and the numbers of those with mental health problems increase. Children in the fast developing tiger countries brought up under the Confucian tradition may experience additional stressors to achieve, and only children, who must satisfy the aspirations of all their grandparents, may be under particular pressure. In a study of 21919 - 12 year olds in primary school in urban and rural areas of the Zheijiang Province in Eastern China [25], the vast majority of these children were "onlys". Eighty-one per cent worried "a lot" about exams; 63 per cent were afraid of punishment by their teachers; and 73 per cent were physically punished by their parents. The authors noted particular concerns about the 8 per cent of children who scored near maximum points on the stress scale. They concluded that the competitive and punitive educational environment led to high levels of stress and psychosomatic symptoms.

In a paper published in 2002, Hesketh et al. [26] noted that the suicide rate in China is estimated to be around three times the global average, with women in the 15- to 24-year-old age group particularly vulnerable. In her study of 1576 adolescents, one-third of the students had suffered symptoms of severe depression, with 16 per cent admitting to suicide ideation and 9 per cent to actually having attempted this. There was very little professional help available. Most young people sought help from family and friends.

"Tiger mothers" are not only a feature East Asia. To a lesser degree, in the West, a whole industry has grown up around parenting and how to maximise children's attainment. Whereas for some families this may be helpful, for others it may place unbearable pressure on their children. A recent Ipsos Mori poll for the Sutton Trust found that $24 \%$ of all young people in the UK have received private tuition at some point; in London, the figure rises to $40 \%$ [27].

The Office for National Statistics in the UK notes that one in ten children between the ages of one and 15 have a mental health disorder [28].

\section{Impact on Parents}

Many parents in their 50s and 60s find themselves caught in the financial and emotional squeeze of the "sandwich generation" [29]. The shift from the high mortality and high-fertility family to a low-mortality and low fertility society has resulted in an increase in the number of generations and a decrease in the number of living relatives within these generations. In the West, at the beginning of the twentieth century between 4 per cent and 7 per cent of people in their 60s had at least one parent still living. Today, this figure is nearly 50 per cent. This has become known as the "beanpole" family [30]. At the same time young people are choosing to delay transitions in adulthood, such as leaving the parental home, achieving full economic independence from parents, marriage, and the birth of their first child. The number of individuals therefore who will live for part of their lives as members of three and four generation families is increasing, as is the proportion of grandparents among western populations. Grandparents Plus, report that 28 per cent of grandparents in the United Kingdom, caring for grandchildren under 16, are effectively in a double "sandwich"-looking after older relatives as well as helping out with their own children and grandchildren. Overall one in five (19 per cent) grandmothers and 14 per cent of grandfathers provide more than ten hours childcare per week. One in five (21 per cent) children is cared for by grandparents each week [31].

But this is only part of the story. In the UK, as recently as 1990, only 25 per cent of those between 18 and 24 lived with their parents. By 2000, the number had gone up to 52 per cent and during the recession this figure is likely to have increased [32]. At the centre of this "squeeze" will be the working and active middle generation and the grandparents. Just as women shoulder much of the childcare responsibilities within two-parent households even when both parents are working, the same is true for elder care [33]. Evidence suggests that "sand- 
wiched" workers were significantly more likely to be stressed than those who provided care for just one generation [34].

In Asian and the developing world, multi-generational families are more common, or indeed the norm [35]. In Singapore sixty-seven per cent of older Singaporeans live with their children while 27 per cent live with their children and grandchildren. In the UK, data from the English Longitudinal Study of Ageing (ELSA) 40 collected in 2008/9 suggests that just over two per cent of older people aged 50 and above live with a grandchild [36]. These multigenerational families offer care for the elderly and care for children but urbanization and the cost of town housing make it more difficult for families to live together, even if they want to.

\section{Looking into the Crystal Ball: Impact on Policy}

Is the decline in fertility rates just a blip in the ups and downs of population statistics? Is there likely to be another baby boom? In the UK, for example, the Total Fertility Rate rose from a record low of 1.63 in 2001 to over 1.94 in 2012 raising prospects of a new baby boom, but fell back in 2013, to 1.85 children per woman (still below replacement rate of 2.1). The Office for National Statistics on further analysis suggests that a possible reason for the increase is the proportion of births to mothers born outside the UK. In 2013 the proportion of these births was $26.5 \%$ compared to 1990 when it was $11.6 \%$ [11].

Overall, however, although there are variations within, and between, different areas, in most parts of the world fertility is declining rapidly or has stabilised at quite low levels. High fertility in sub-Sahara Africa is predicted to fall with increasing economic well-being, the growing availability and acceptability of contraception, and the increase in the education of girls.

\subsection{With a Smaller Population Children Will Become More Valuable?}

The central finding is that, with fewer children, in both the developed and developing world, all children will become more valuable, both the privileged few and those who to date have experienced harder times. Gøsta Esping-Andersen [37] makes a strong case that we need to invest more in the early years of our existing children, particularly children living in poverty. The distinguished US economist, James Heckman [38] showed the possible economic returns from investment in early years' education for poorer children. Heckman's work, noted by Esping Andersen, argues that the rate of return from investing in the early years is greater than investing at any other time of a child's life. Recent research on the brain has added fuel to this debate. The brain is a developing organ at birth, and is most sensitive to experiences in infancy and childhood. The child's inherited potential is designed to work in a certain kind of environment. The brain has sensitive periods and although this may be marginally different for each child, the most sensitive period is around birth and during the first three years. [39].

\subsection{More Women Will Be Needed to Fill the Gaps in a Declining Workforce}

Lee Kuan Yew famously lamented that educating women and giving them opportunities in the labour force had affected their traditional role as mothers.

"It is too late for us to reverse our policies. ... Our women will not stand for it. And anyway, they have already become too important a factor in the economy" (Lee 2006, p. 115) [40].

In 2006, the Economist published an interesting article: "a guide to womenomics: The future of the world economy lies increasingly in female hands" [41]. Their point was that working women were playing an increasing role in the growth of national economies. They noted, for example, that in the emerging East Asian economies, for every 100 men in the labour force there were now 83 women, which was higher than in many OECD countries (the 34 democratic countries who are members of the Organisation for Economic Co-operation and Development). They concluded that the increase in female employment had been responsible for much global growth in recent decades. In a further article in the Economist they concluded that:

"Governments, too, should embrace the potential of women. Women complain (rightly) of centuries of exploitation. Yet, to an economist, women are not exploited enough: they are the world's most under-utilised resource; getting more of them into work is part of the solution to many economic woes, including shrinking populations and poverty” [42] (Economist, 2006). 


\subsection{If More Women Enter and Remain in the Workforce, Societies Will Need to Do More to Help Them with Their Work/Family Balance}

Gauthier [43] in outlining family/friendly policy instruments available to women in Europe, notes that although these policies are only marginally associated with an increasing fertility rate, such policies help make work and family responsibilities more manageable. However, although work-life "balance" is an EU policy priority, across Europe there are considerable variations in the nature and extent of supports that national governments have offered to dual-earner families. Countries, such as France, have historically offered extensive childcare supports to working mothers although their parental leaves are relatively short [44]. This report found evidence of a "societal effect" in the cases of Finland and Norway. There were significantly lower levels of work-life conflict reported in these countries even after a range of factors had been controlled. Surprisingly, childcare in France did not appear to have had a similar impact. The authors surmised that this finding may have been related to the more traditional division of labour in France, notably the low participation of men in domestic chores and child care, which is associated with higher levels of stress.

Other authors [45] note that there is now considerable evidence that family-friendly initiatives can lead to significant improvements in economic benefits for companies, for example in recruiting; lower levels of absenteeism and voluntary turnover; increased productivity, organizational commitment and loyalty; job satisfaction; as well as lower stress levels, and health care costs.

Parents will also need time to care for their parents, and family policies will need to facilitate the care of the elderly. Subsidized elder care has been highlighted [45] as an important company initiative. It is said "Child care used to be the topic of discussion at parties... Now it's ageing parents." [46].

Finally we need to think about the psychological well-being of our future children. In a fast changing world, children and young people will need to be resilient to the many changes that will happen during their lives. They will need to be psychologically strong. There are important links between maternal mental health and that of children [47]. If we want our children to be resilient to the pressures of the changing world; to have steady state and self esteem to cope, we need to think about the well-being of their parents, especially mothers. We also need to think how we can better promote the well-being of children (remembering, especially, those children who have not prospered and those who have been intensely pressurised), and do what we can, not only as parents, but also as representatives of societies, to make time for them. Modern science has shown that there is much we can do to ensure that not only our children are healthier and better educated to thrive in an increasingly complex world, but there is also much that Governments, the world over, can do by developing the family policies that enable children and their parents to thrive so that they can all contribute in a fast changing scenario

\section{References}

[1] United Nations (2013) World Fertility Patterns 2013. http://www.un.org/en/development/desa/population/publications/pdf/fertility/world-fertility-patterns-2013.pd

[2] Jones, G. (2013) The Growth of the One-child Family and Other Changes in the Low Fertility Countries of Asia. In: Buchanan, A. and Rotkirch, A., Eds., Fertility Rates and Population Decline: No Time for Children? Palgrave Macmillan, London. http://dx.doi.org/10.1057/9781137030399.0008

[3] Buchanan, A. and Rotkirch, A. (2013) Falling Fertility and Population Decline: No Time for Children. Palgrave Macmillan, London. http://dx.doi.org/10.1057/9781137030399

[4] Roberts, J., Williams, K. and Buchanan, A. (2013) Why Are Women Having Fewer Children: The Views of Mumsnet Users. In: Buchanan, A. and Rotkirch, A., Eds., Fertility Rates and Population Decline: No Time for Children? Palgrave Macmillan, London.

[5] Zheng, Z.Z. (2013) The Choice of Having a Second Child and Its Implications for Future Family Structure in China. In: Buchanan, A. and Rotkirch, A., Eds., Fertility Rates and Population Decline: No Time for Children? Palgrave Macmillan, London. http://dx.doi.org/10.1057/9781137030399.0015

[6] Perelli-Harris, B and Issoupova, O. (2013) Crisis and Control: Russia’s Dramatic Fertility Decline and Efforts to Increase It. In: Buchanan, A. and Rotkirch, A., Eds., Fertility Rates and Population Decline: No Time for Children? Palgrave Macmillan, London.

[7] Benton, L. and Newell, M.-L. (2013) Childbearing and the Impact of HIV: The South African Experience. In: Buchanan, A. and Rotkirch, A., Eds., Fertility Rates and Population Decline: No Time for Children? Palgrave Macmillan, London. http://dx.doi.org/10.1057/9781137030399.0016

[8] Haskey, J. (2013) Childlessness: Choice and Circumstances. In: Buchanan, A. and Rotkirch, A., Eds., Fertility Rates 
and Population Decline: No Time for Children? Palgrave Macmillan, London, 62-81. http://dx.doi.org/10.1057/9781137030399.0009

[9] Rotkirch, A. (2013) Baby Fever and Longing for Children. In: Buchanan, A. and Rotkirch A., Eds., Fertility Rates and Population Decline: No Time for Children? Palgrave Macmillan, London, 249-266. http://dx.doi.org/10.1057/9781137030399.0022

[10] Basten, S. (2013) Declining Fertility, Television and the (Mis) Representation of Motherhood. In: Buchanan, A. and Rotkirch, A., Eds., Fertility Rates and Population Decline: No Time for Children? Palgrave Macmillan, London, 185202. http://dx.doi.org/10.1057/9781137030399.0017

[11] Office for National Statistics (2013) Births in England and Wales by Parents’ Country of Birth, 2012. http://www.ons.gov.uk/ons/dcp171778_325310.pdf

[12] Harper, S. (2013) Falling Fertility, Ageing and the Demographic Deficit. In: Buchanan, A. and Rotkirch, A., Eds., Fertility Rates and Population Decline: No Time for Children? Palgrave Macmillan, London, 221-229. http://dx.doi.org/10.1057/9781137030399.0020

[13] Grandparent Plus (2013) Press Release. Time to Care about Kinship Care. http://www.grandparentsplus.org.uk/press-release

[14] United Nations Data Statistics (2011) UN: Page 1. http://data.un.org/Data.aspx?d=SOWC\&f=inID\%3A127.

[15] United National Development Programme (2010) UNDP Report 2010. http://hdr.undp.org/en/reports/global/hdr2010/chapters/en/

[16] United National Development Programme (2010) UNDP Report 2010, Page 3. http://hdr.undp.org/en/reports/global/hdr2010/chapters/en/

[17] United National Development Programme (2009) UNDP Report 2009, Gini Index. http://hdrstats.undp.org/en/indicators/161.html

[18] Miller, B.D. (2001) Female-Selective Abortion in Asia: Patterns, Policies and Debates. American Anthropologist, 103, 1083-1095. http://dx.doi.org/10.1525/aa.2001.103.4.1083

[19] Fenton, N. (1928) The Only Child. Journal of Genetic Psychology, 35, 546-556.

[20] Falbo, T. and Polit, D. (1986) Quantitative Review of the Only Child Literature: Research Evidence and Theory Development. Psychological Bulletin, 100, 176-189. http://dx.doi.org/10.1037/0033-2909.100.2.176

[21] Van Gaalen, R.I., Dykstra, P.A. and Flap, H. (2008) Intergenerational Contact beyond the Dyad: The Role of the Sibling Network. European Journal of Ageing, 5, 19-29. http://dx.doi.org/10.1007/s10433-008-0076-6

[22] Wellman, B. and Wortley, S. (1989) Brothers’ Keepers: Situating Kinship Relations in Broader Networks of Social Support. Sociological Perspectives, 32, 273-306. http://dx.doi.org/10.2307/1389119

[23] Legge, J. (1893) Lun Yu (The Analects). Clarendon Press, Oxford.

[24] Layard, R. (2005) Happiness: Lessons from a New Science. Penguin Group USA, London.

[25] Hesketh, T., Zhen, Y., Lu, L., Dong, Z.X., Jun, Y.X. and Xing, Z.W. (2009) Stress and Psychosomatic Symptoms in Chinese School Children: Cross Sectional Survey. Archives of Disease in Childhood, 95, 136-140. http://dx.doi.org/10.1136/adc.2009.171660

[26] Hesketh, T., Ding, Q.J. and Jenkins, R. (2002) Suicide Ideation in Chinese Adolescents. Social Psychiatry and Psychiatric Epidemiology, 37, 230-235. http://dx.doi.org/10.1007/s00127-002-0536-9

[27] The Guardian (2014) The New Boom in Home Tuition-If You Can Pay £40 an Hour. http://www.theguardian.com/education/2013/oct/25/new-boom-home-tuition.

[28] Office for National Statistics (2005) Mental Health in Children and Young People in Great Britain. http://www.mentalhealth.org.uk/help-information/mental-health-statistics/children-young-people/

[29] Grundy, E. and Henretta, J. (2006) Between Elderly Parents and Adult Children: A New Look at the Intergenerational Care Provided by the "Sandwich Generation". Ageing and Society, 26, 707-722. http://dx.doi.org/10.1017/S0144686X06004934

[30] Bengtson, V.L. and Martin, P. (2001) Families and Intergenerational Relationships in Aging Societies: Comparing the United States with German-Speaking Countries. Zeitschrift für Gerontologie und Geriatrie, 34, 207-217. http://dx.doi.org/10.1007/s003910170065

[31] Grandparent Plus (2012) Report of Seminar. http://www.grandparentsplus.org.uk/conferences-and-seminars

[32] O’Brien, S. (2012) How to Avoid Sandwich Generation Problems. http://seniorliving.about.com/od/babyboomers/a/sandwich-generation.htm.

[33] Ward, R. and Spitze, G. (1998) Sandwiched Marriages: The Implications of Child and Parent Relations for Marital 
Quality in Midlife. Social Forces, 77, 647-666.

[34] Williams, C. (2004) The Sandwich Generation, Perspectives 5-12, Statistics Canada, Catalogue 75-001-XIE. http://ivt.crepuq.qc.ca/popactive/documentation2005_A/2004/2004-09-01.pdf

[35] ILC Global Alliance (2021) Global Perspectives on Multigenerational Households and Intergenerational Relations. http://www.ilc-alliance.org/images/uploads/publicationpdfs/Global_Alliance_Intergenerational_Relations_March_201 2.pdf

[36] Office for National Statistics (2013) Statistical Bulletin: Births in England and Wales, 2013. http://www.ons.gov.uk/ons/dcp171778_371129.pdf

[37] Esping-Andersen, G. (2013) Chapter 17: Investing in Early Childhood. In: Buchanan, A. and Rotkirch, A., Eds., Fertility Rates and Population Decline: No Time for Children? Palgrave Macmillan, London, 288-302.

[38] Heckman and Masterov (2007) The Productivity Argument for Investing in Young Children. Applied Economic Perspectives and Policy 29, 3, 446-493.

[39] Perry, B.D. (2002) Childhood Experience and the Expression of Genetic Potential: What Childhood Neglect Tells Us about Nature and Nurture. Brain and Mind, 3, 79-100. http://dx.doi.org/10.1023/A:1016557824657

[40] Lee, Y.-J. (2006) Risk Factors in the Rapidly Rising Incidence of Divorce in Korea. Asian Population Studies, 2, 113132. http://dx.doi.org/10.1080/17441730600923091

[41] Economist (2006) A Guide to Womenomics: The Future of the World Economy Lies Increasingly in Female Hands. http://www.economist.com/node/6802551

[42] Economist (2006) The Importance of Sex. Forget China, India and the Internet: Economic Growth Is Driven by Women. http://www.economist.com/node/6800723

[43] Gauthier, A.H. (2013) Chapter 16: Family Policy and Fertility: Do Policies Make a Difference? In: Buchanan, A. and Rotkirch, A., Eds., Fertility Rates and Population Decline: No Time for Children? Palgrave Macmillan, London, 269287.

[44] Compton, R. and Lyonette, C. (2006) Work-Life "Balance” in Europe. Acta Sociologica, 49, 379-393.

[45] Hobson, C.J., Delunas, L. and Kesic, D. (2011) Compelling Evidence of the Need for Corporate Work/Life Balance Initiatives: Results from a National Survey of Stressful Life-Events. Journal of Employment Counselling, 38, 38-44. http://dx.doi.org/10.1002/j.2161-1920.2001.tb00491.x

[46] Shea, T.F. (2003) Help with Elder Care: Elder Care Benefits Range from Basic to Comprehensive as Employers Help Employees Cope with This Growing Need. HR Magazine: Compensation \& Benefits Agenda, 48, No. 9. http://www.shrm.org/Publications/hrmagazine/EditorialContent/Pages/0903shea.aspx

[47] Burke, L. (2003) The Impact of Maternal Depression on Familial Relationships. International Review of Psychiatry, 15, 243-255. http://dx.doi.org/10.1080/0954026031000136866 
Scientific Research Publishing (SCIRP) is one of the largest Open Access journal publishers. It is currently publishing more than 200 open access, online, peer-reviewed journals covering a wide range of academic disciplines. SCIRP serves the worldwide academic communities and contributes to the progress and application of science with its publication.

Other selected journals from SCIRP are listed as below. Submit your manuscript to us via either submit@scirp.org or Online Submission Portal.
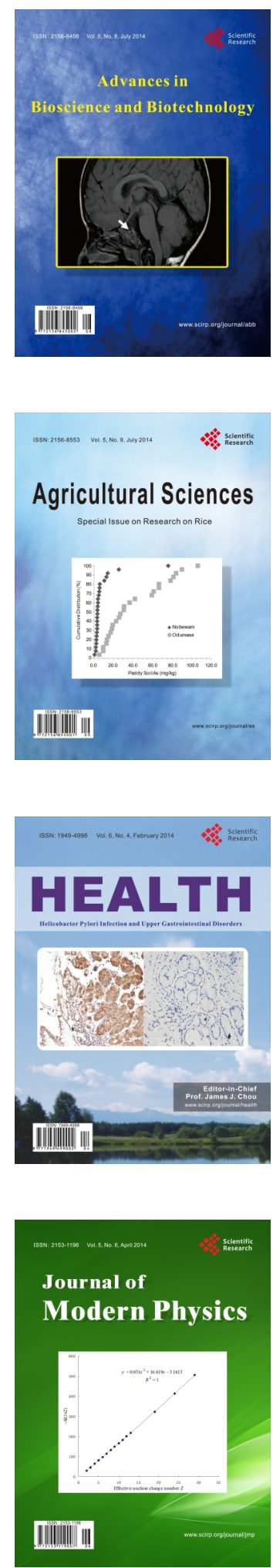
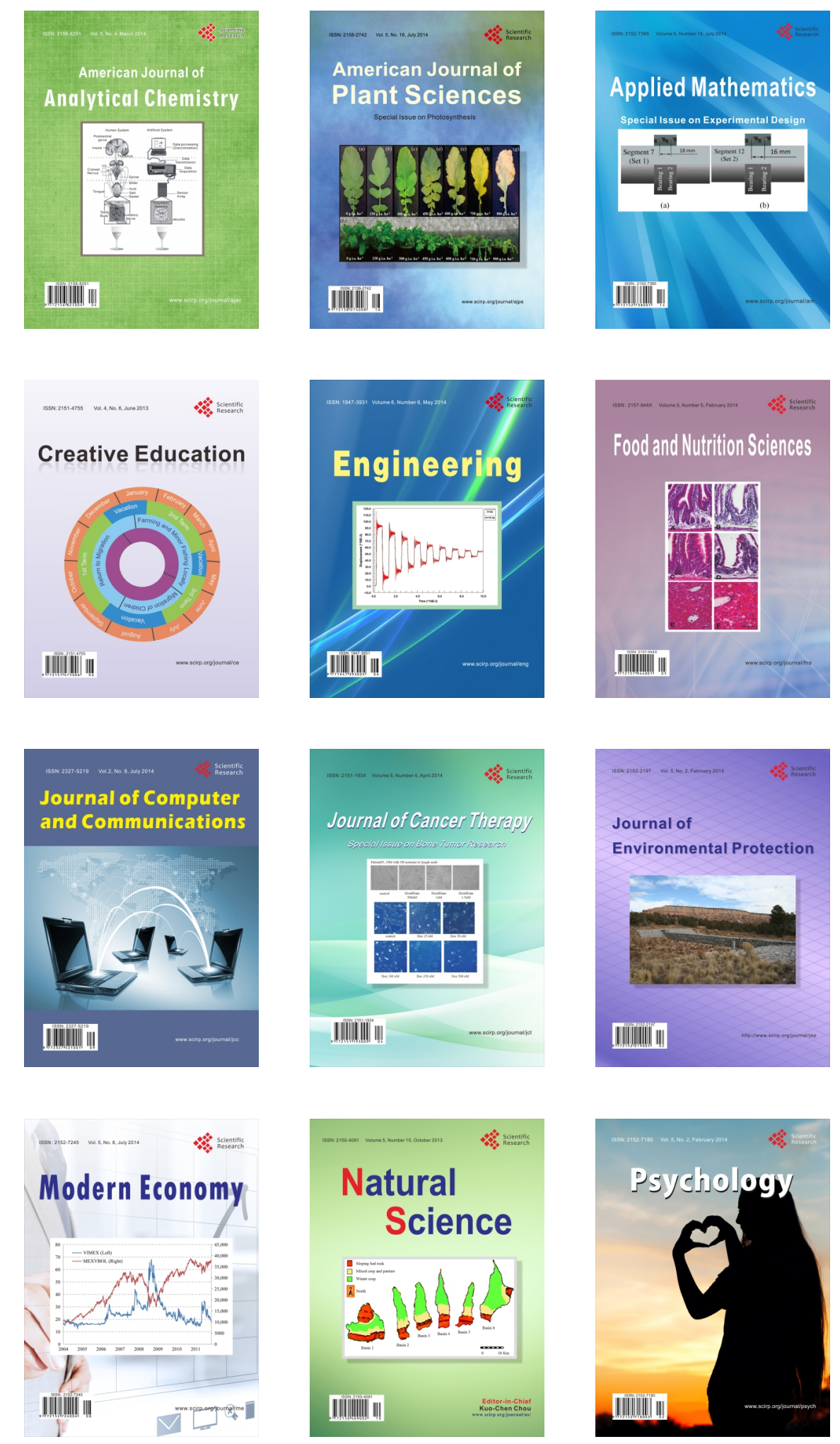